\title{
Comparison of complement-fixing antibody titres in patients with rheumatoid arthritis and matched controls
}

\author{
FRED STANFORD \\ Royal Victoria Hospital, Belfast, N. Ireland
}

Many of the clinical findings in rheumatoid arthritis are consistent with an infectious aetiology. Direct methods of demonstrating infectious agents in rheumatoid tissues have given apparently conflicting results (Bartholomew, 1967; Duthie, Stewart, Alexander, and Dayhoff, 1967; Sharp, 1970).

Indirect evidence, namely the demonstration of differences in titres of antibodies against different antigens between rheumatoid patients and normal people, has again given conflicting results (Smiley and Casey, 1969; Chandler, Robinson and Masi, 1971).

This report describes differences in the complementfixing antibody titres between a group of rheumatoid patients and controls who were matched for age and sex.

\section{Methods}

A preliminary unreported series of comparisons between complement fixing antibodies and rheumatoid factor in different groups of rheumatoid patients showed an inverse correlation between these two variables. For the present comparisons the rheumatoid group contained 23 females and 22 males with ages ranging from 17 to 75 years, all of whom had at least five of the American Rheumatism Association criteria for the diagnosis of rheumatoid arthritis. Because of the above finding the only other selection was to include a wide range of rheumatoid factor titres in their serum as previously estimated by routine laboratory testing. The $\mathbf{4 5}$ age- and sex-matched controls were in-patients suffering from minor orthopaedic, gynaecological, or ophthalmic, and ear, nose, and throat complaints. All were examined to exclude rheumatoid arthritis and other serious illness. They were excluded if there was a family history of arthritis.

Sera from these 90 patients were stored at $-20^{\circ} \mathrm{C}$. Tests were performed in parallel and all sera were heated to $56^{\circ} \mathrm{C}$. for 30 mins before use in complement-fixation (CF) tests for herpes simplex, measles, and mumps virus antigens. These tests were performed in micro-plates using overnight fixation at $4^{\circ} \mathrm{C}$. and $3 \mathrm{MHD}_{s 0}$ of guineapig complement (Bradstreet and Taylor, 1962).

Rheumatoid factor (RF) was measured on heat inactivated sera using Hyland's RA-latex test.
Human gamma globulin (Cohn fraction II), donated by Dr. W. Shepherd of The Laboratories, Belfast City Hospital, was aggregated by heating to $73^{\circ} \mathrm{C}$. for $10 \mathrm{mins}$. The resulting precipitate was washed four times in phosphate-buffered saline and used to remove rheumatoid factor. An equal quantity of precipitate was added to sera in both the rheumatoid and control groups irrespective of the presence of rheumatoid factor. Only one absorption was done on each sample.

An analysis of variance technique was used to assess the results. The least significant differences for the individual comparisons were determined, using the mean square for error and the probability (P) calculated. $\log _{10}$ mean values are shown in the Tables. A correlation coefficient ( $r$ ) was estimated for values of RF and CF antibodies and its significance calculated from the standard error (degrees of freedom $(\mathrm{df})=44)$. The geometric mean was used because of the wide range of rheumatoid factor and complement-fixing antibody titres.

\section{Results}

(a) A comparison of CF antibody titres between the rheumatoid group and the control group

When the CF antibodies were measured against herpes simplex, measles, and mumps virus antigens (Table I), the percentage of controls with antibody varied greatly, herpes simplex antibody being much more common. The percentage of rheumatoid patients with detectable antibody was less than the controls against all three antigens.

Table I Percentage of sera with positive values for CF antibodies in the rheumatoid and control groups against the shown antigens

\begin{tabular}{|c|c|c|}
\hline \multirow[t]{2}{*}{ Antigens } & \multicolumn{2}{|c|}{ Percentage positive } \\
\hline & Rheumatoid & Control \\
\hline $\begin{array}{l}\text { Herpes simplex } \\
\text { Measles } \\
\text { Mumps }\end{array}$ & $\begin{array}{l}67 \\
27 \\
24\end{array}$ & $\begin{array}{l}80 \\
51 \\
42\end{array}$ \\
\hline
\end{tabular}


Comparison of the mean titres of antibody (Table II) showed that the control group had significantly higher titres than the rheumatoid group for each of the antigens tested.

Table II $\log _{10}$ geometric mean titres of directly measured $C F$ antibodies in rheumatoid patients and controls

\begin{tabular}{|c|c|c|c|}
\hline \multirow[t]{2}{*}{ Antigens } & \multicolumn{2}{|l|}{ Group } & \multirow{2}{*}{$\begin{array}{l}\text { Probability } \\
\text { for S.E.D }\end{array}$} \\
\hline & Rheumatoid & Control & \\
\hline $\begin{array}{l}\text { Herpes } \\
\text { simplex } \\
\text { Measles } \\
\text { Mumps }\end{array}$ & $\begin{array}{l}0.656 \\
0.241 \\
0.141\end{array}$ & $\begin{array}{l}0.890 \\
0.388 \\
0.245\end{array}$ & $\begin{array}{l}\mathrm{P}<0.001 \\
\mathrm{P}<0.01 \\
\mathrm{P}<0.01\end{array}$ \\
\hline
\end{tabular}

(b) Comparison between the titres of CF antibodies and the titre of rheumatoid factor

Only four of the 45 control patients had detectable rheumatoid factor and these were at titres of less than $1: 10$. Of the 45 rheumatoid patients, 36 gave positive reactions. Comparison of rheumatoid factor titres with CF antibody titres in this group (Table III) shows negative $r$ values pointing to an inverse correlation for the antibodies against the three antigens tested. These correlations are all significant but the most marked is that for herpes simplex $(\mathrm{P}<0.001)$.

Table III An analysis of the degree of correlation between levels of rheumatoid factor and CF antibodies to the shown antigens for 45 rheumatoid patients

\begin{tabular}{lll}
\hline Antigens & $\begin{array}{l}\text { Correlation } \\
\text { Coefficient }(r) \\
(d f=44)\end{array}$ & $\begin{array}{l}\text { Probability }(P) \\
\text { calculated from } \\
\text { the standard } \\
\text { error }\end{array}$ \\
\cline { 2 - 2 } $\begin{array}{l}\text { Herpes Simplex } \\
\text { Measles }\end{array}$ & $\begin{array}{l}\mathbf{P}=-0.75 \\
\text { Mumps }\end{array}$ & $\begin{array}{l}\mathbf{P}<0.001 \\
\mathbf{P}<0.01\end{array}$ \\
& $r=-0.43$ & $\mathrm{P}<0.01$ \\
\hline
\end{tabular}

The distribution of antibody titres for this antigen and rheumatoid factor are shown in Fig. 1.

(c) A comparison of CF antibody titres between the rheumatoid group and controls after removal of rheumatoid factor

The rheumatoid factor present in the control group was completely removed by the aggregated gamma globulin. In five of the seropositive rheumatoid group, a low titre $(<1: 10)$ of rheumatoid factor persisted after the absorption. None of the sera were anticomplementary either before or after treatment.

Treatment with aggregated gamma globulin made no significant difference to the titres of antibody

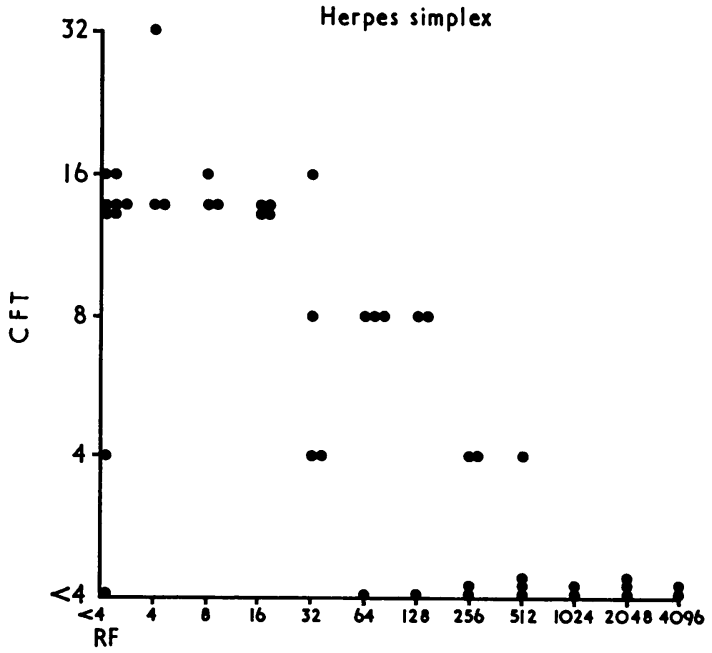

FIG. 1 A comparison of herpes simplex CF antibody titres with rheumatoid factor titres in a group of 45 rheumatoid patients

against any of the viral antigens in the control group $(P>0.05)$. However, in the rheumatoid group, there was a significant increase in titre of antibodies against herpes simplex, measles, and mumps antigens compared with preabsorption values $(\mathrm{P}<0.001)$.

Comparison of the mean titres after absorption for the two groups (Table IV) shows that there is now no significant difference for the mumps antibody titres $(P>0.05)$. The titres of herpes simplex and measles antibody are now significantly greater in the rheumatoid group than in the controls (measles, $P<0.001$; herpes simplex, $P<0.01$.)

Table IV $\log _{10}$ geometric mean titres of CF antibodies after absorption of rheumatoid factor by aggregated gammaglobulin

\begin{tabular}{|c|c|c|c|}
\hline \multirow[t]{2}{*}{ Antigens } & \multicolumn{2}{|l|}{ Group } & \multirow{2}{*}{$\begin{array}{l}\text { Probability } \\
\text { for S.E.D }\end{array}$} \\
\hline & Rheumatoid & Control & \\
\hline $\begin{array}{l}\text { Herpes } \\
\text { simplex } \\
\text { Measles } \\
\text { Mumps }\end{array}$ & $\begin{array}{l}1.032 \\
0.626 \\
0.291\end{array}$ & $\begin{array}{l}0.878 \\
0.421 \\
0.298\end{array}$ & $\begin{array}{l}P<0.01 \\
P<0.001 \\
\text { Not sig- } \\
\text { nificant } \\
P>0.05\end{array}$ \\
\hline
\end{tabular}

The distribution of herpes simplex antibody titres in the rheumatoid group after absorption is compared with the pre-absorption rheumatoid factor titres in Fig. 2. Referral to Fig. 1 shows the change from preabsorption antibody levels.

(d) Comparison of complement-fixing antibodies with other variables in the rheumatoid group

Of the 23 female patients irrespective of other treatment, ten were receiving gold therapy and four 
FIG. 2 A comparison of the scatter of results for

herpes simplex $C F$ antibodies in 45 controls and 45

rheumatoid patients after removal of rheumatoid factor. The preabsorption rheumatoid factor titres are shown for comparison with the results in Fig. 1 for the rheumatoid group

steroids; of the 22 males two were receiving gold and eleven steroids. Generally, those on gold therapy had low titres of rheumatoid factor, i.e. the female patients. Complement-fixing antibody was found slightly more commonly in females than in males before absorption of rheumatoid factor, i.e. seventeen of the 23 females and thirteen of the 22 males had antibody for herpes simplex. After absorption with aggregated gamma globulin, the values became similar. With some notable exceptions there was a tendency for rheumatoid factor titres to rise with age of patient, duration of illness, and erythrocyte sedimentation rate. Any relationship between complement-fixing antibody titres and age, duration of illness, and erythrocyte sedimentation rate seemed to be allied to the corresponding titre of rheumatoid factor and disappeared after absorption with aggregated gamma globulin.

\section{Discussion}

The present results show that $\mathrm{CF}$ antibodies against herpes simplex antigen are much more frequently found in the control population than either measles or mumps antibody. The differences in titre between the rheumatoid and control groups were more marked for the directly measured herpes simplex CF antibody $(P<0.001)$ than for either measles or mumps antibody $(P<0.01)$.

Smiley and Casey (1969) demonstrated decreased herpes simplex but normal rubella, adenovirus, mumps, and psittacosis-lymphogranuloma CF antibodies in a group of 21 rheumatoid patients. Simsarian, Roth, Hopps, Douglas, Williams, and Meyer

(1970) showed a similar decrease for herpes simplex but not for mumps or varicella-zoster CF antibodies in 27 rheumatoid patients compared with controls. The discrepancy from the present results may be explained by the lower number of patients tested by the other investigators especially if the presence of $\mathrm{CF}$ antibody is not as frequent as for herpes simplex.

An inverse correlation between the titres of directly measured CF antibodies and rheumatoid factor is also shown in the present results. This confirms the finding of Bach, Grieble, and Anderson (1965) of an inverse correlation between the presence of rheumatoid factor and CF antibodies to parainfluenza II, adenovirus, and respiratory syncytial virus in 231 aged people. Brown, Clarke, and Bailey (1970) showed a similar phenomenon in rheumatoid patients for mycoplasma CF antibodies.

Because of the above relationship it was necessary to remove rheumatoid factor to measure true titres of CF antibodies in the rheumatoid group. Gamma globulin (Cohn fraction II) aggregated by different methods has frequently been used as a method for removal of rheumatoid factor, i.e. Christian (1958) and Torrigiani and Roitt (1967). Extraction of the control sera did not alter the CF antibody titres which indicated that the post-absorption titres for the rheumatoid group must be true antibody titres. The true mumps antibody titres were similar in the two groups, but the rheumatoid patients had higher CF antibody titres against both herpes simplex and measles antigens than the controls. Chandler and others (1971), using 22 newly-diagnosed rheumatoid patients, found an increased titre of herpes simplex CF antibody compared with controls. Rheumatoid factor titres tend to be low early in the course of rheumatoid disease. This may explain the similarity of the results in this group of patients to the postabsorption results in the present group of rheumatoid patients.

The effect of removal of rheumatoid factor as shown in the above results would fit in with the interaction between rheumatoid factor and complement as shown by Heimer, Levin, Primack, Corcos, and Nosenzo (1962) and Schmid and Rocha (1968).

In sera of patients with systemic lupus erythematosus, Phillips and Christian (1970) showed raised haemagglutination inhibition (HI) antibody against the myxovirus group antigens of measles and parainfluenza II. Hurd, Dowdle, Casey, and Ziff (1970) demonstrated raised $\mathrm{CF}$ and $\mathrm{HI}$ antibodies to a much wider range of viral antigen groups in these patients. The raised antibody titres found in the rheumatoid arthritis patients in the present study may resemble a pattern for other collagen diseases. Despite the raised levels of antibody, there is insufficient evidence to suggest at the present that any of the viruses are causative agents or that the rheumatoid group suffer more severe viral illnesses. 
The above results should be considered when investigating the seropositive rheumatoid patient for any other illness using the complement-fixation technique, as the antibody titres may be falsely low or negative. The low titres of rheumatoid factor developed in nonrheumatoid patients are unlikely to interfere with routine testing.

\section{Summary}

Using a group of 45 rheumatoid patients and 45 age- and sex-matched controls, it was demonstrated that the rheumatoid group had lower mean titres of CF antibody against herpes simplex, measles, and mumps antigens on direct testing. There was an inverse relationship between the titre of rheumatoid factor and the titre of CF antibody. Removal of rheumatoid factor reveals higher titres of CF antibody. The true titre against mumps antigen was the same in the two groups. The true titres against herpes simplex and measles antigen were higher in the rheumatoid than in the control group.

The significance of the above results is discussed.

I am indebted to Prof. K. B. Fraser and Dr. J. H. Connolly of the Department of Microbiology, The Queen's University of Belfast, and Dr. S. D. Roberts of the Royal Victoria Hospital, Belfast, for their encouragement and guidance throughout the course of this study. The statistical analyses were kindly carried out by Dr. K. D. MacRae of the Department of Medical Statistics, The Queen's University of Belfast. The author is in receipt of a Research Fellowship from the Royal Victoria Hospital, Belfast. This work is also financed by a research grant to Prof. Fraser from the Arthritis and Rheumatism Council.

\section{References}

BaCH, G. L., Grieble, H. G., AND ANDerson, T. O. (1965) Clin. Res., 13, 284 (Immunopathology in the aged) BARTHOLOMEW, L. E. (1967) Ann. N.Y. Acad. Sci., 143, 552 (Characterization of mycoplasma strains and antibody studies from patients with rheumatoid arthritis)

Bradstreet, C. M. P., AND TAYlor, C. E. D. (1962) Monthly Bulletin of the Ministry of Health and The Public Health Laboratory Service, 21, 96 (Technique of complement-fixation test applicable to the diagnosis of virus diseases

Brown, T. McP., Clark, H. W., and Bailey, J. S. (1970) Arthr. and Rheum., 13, 309 (Relationship between mycoplasma antibodies and rheumatoid factors)

Chandler, R. W., Robinson, H., ANd Masi, A. T. (1971) Ann. rheum. Dis., 30, 274 (Serological investigations for evidence of an infectious aetiology of rheumatoid arthritis)

Christian, C. L. (1958) J. exp. Med., 108, 139 (Characterization of the 'reactant' (gamma globulin factor) in the $F_{11}$ precipitin reaction and the $F_{11}$ tanned sheep cell agglutination test)

Duthie, J. J. R., STewart, S. M., AleXander, W. R. M., AND Dayhoff, R. E. (1967) Lancet, 1, 142 (Isolation of diphtheroid organisms from rheumatoid synovial membrane and fluid)

Heimer, R., Levin, F. M., Primack, A., Corcos, J. M., ANd Nosenzo, C. (1962) J. Immunol., 89, 382 (Inhibition of complement fixation by human sera)

Hurd, E. R., Dowdle, W., CASEY, H., AND ZifF, M. (1970) Arthr. and Rheum., 13, 324 (Virus antibody levels in systemic lupus erythematosus)

Phillips, P. E., AND Christian, C. L. (1970) Science, 168, 982 (Myxovirus antibody increases in human connective tissue disease)

Schmid, F. R., AND Rocha, M. D. (1968) Arthr. and Rheum., 11, 508 (Inhibition and enhancement of complement action by rheumatoid factor)

ShaRP, J. T. (1970) Arthr. and Rheum., 13, 263 (Mycoplasmas and arthritis)

Simsarian, J. P., Roth, H., Hopps, H., Douglas, R., Williams, M. S., AND Meyer, H. M., Jr. (1970) Ibid., 13, 348 (Serological and virological studies in patients with rheumatoid arthritis)

Smiley, J. D., AND CASEY, H. L. (1969) Ibid., 12, 698 (Decreased C. F. antibodies in sera and decreased lymphocyte transformation to herpes simplex in patients with rheumatoid arthritis) (Abstr.)

TorrigianI, G., AND RoITt, I. M. (1967) Ann. rheum. Dis., 26, 334 (Antiglobulin factors in sera from patients with rheumatoid arthritis and normal subjects) 